\title{
Article
}

\section{Once in a lifetime: the date of the Wayland's Smithy long barrow}

Wysocki, Michael Peter, Bayliss, A and Whittle, A

Available at http://clok.uclan.ac.uk/323/

Wysocki, Michael Peter, Bayliss, A and Whittle, A (2007) Once in a lifetime: the date of the Wayland's Smithy long barrow. Cambridge Archaeological Journal, 17 (S1). pp. 103-121. ISSN 14740540

It is advisable to refer to the publisher's version if you intend to cite from the work. http://dx.doi.org/10.1017/S0959774307000194

For more information about UCLan's research in this area go to

http://www.uclan.ac.uk/researchgroups/ and search for <name of research Group>.

For information about Research generally at UCLan please go to http://www.uclan.ac.uk/research/

All outputs in CLoK are protected by Intellectual Property Rights law, including Copyright law. Copyright, IPR and Moral Rights for the works on this site are retained by the individual authors and/or other copyright owners. Terms and conditions for use of this material are defined in the policies page.

\section{CLoK}

Central Lancashire online Knowledge www.clok.uclan.ac.uk

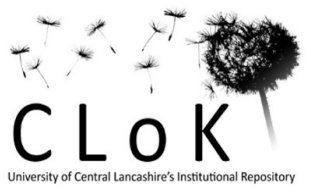




\title{
Once in a Lifetime: the Date of the Wayland's Smithy Long Barrow
}

\author{
Alasdair Whittle, Alex Bayliss \& Michael Wysocki
}

Twenty-three radiocarbon results are now available from the Wayland's Smithy long barrow, and are presented within an interpretive Bayesian statistical framework. Four alternative archaeological interpretations of the sequence are considered, each with a separate Bayesian model, though only two are presented in detail. The differences are based on different readings of the sequence of Wayland's Smithy II. In our preferred interpretation of the sequence, the primary mortuary structure was some kind of lidded wooden box, accessible for deposition over a period of time, and then closed by the mound of Wayland's Smithy I; Wayland's Smithy II was a unitary construction, with transepted chambers, secondary kerb and secondary ditches all constructed together. In the Bayesian model for this interpretation, deposition began in the earlier thirty-sixth century cal. $B C$, and probably lasted for a generation. A gap of probably 40-100 years ensued, before the first small mound was constructed in 3520-3470 cal. вс. After another gap, probably of only 1-35 years, the second phase of the monument was probably constructed in the middle to later part of the thirty-fifth century cal. $B C$ (3460-3400 cal. $\mathrm{BC})$, and its use probably extended to the middle decades of the thirty-fourth century cal. $B$. Results are discussed in relation to the local setting, the nature of mortuary rites and the creation of tradition.

The Wayland's Smithy long barrow lies some $25 \mathrm{~km}$ northeast of the West Kennet long barrow, along the Ridgeway, close to the north scarp of the Downs above the Vale of the White Horse in southern Oxfordshire (SU 2811 8536; 51 ${ }^{\circ} 33^{\prime} 59^{\prime \prime} \mathrm{N}, 01^{\circ} 35^{\prime} 45^{\prime \prime} \mathrm{W}$ ). With its nearest neighbour, the Lambourn long barrow, about $5 \mathrm{~km}$ to the southeast, the monument more or less defines the southeastern limits of the Cotswold-Severn group of chambered tombs (Corcoran 1969a,b; Darvill 2004; Whittle 1991).

The monument is as well known as West Kennet and the site has a long history, going back to its first mention in a charter of King Eadred, dated to AD 955, and antiquarian observations by Aubrey, Wise, Colt Hoare and others. The first recorded excavations were in 1919-20 (Peers \& Smith 1921). This has all been summarized by Whittle (1991), who presented the full report of excavations undertaken in 1962 and 1963 by Stuart Piggott and Richard Atkinson.
Those excavations revealed that the trapezoidal long mound, with a single transepted megalithic chamber at its southern end (Wayland's Smithy II), had been built over, and had concealed, an earlier oval barrow with a sarsen and timber mortuary area (Wayland's Smithy I) (Fig. 1).

\section{Wayland's Smithy I}

The mortuary structure, containing substantial human remains (see below), was covered by a small oval barrow of chalk rubble and earth, derived from two curved flanking ditches. The structure itself was defined by a rectangular paved area of sarsen slabs, flanked and partially overlain at its edges by two linear sarsen cairns. The north and south margins of the paved area were marked by two large $\mathrm{D}$-shaped post pits. Atkinson $(1965,130)$ interpreted these features as part of a tent-like structure with a ridge and 


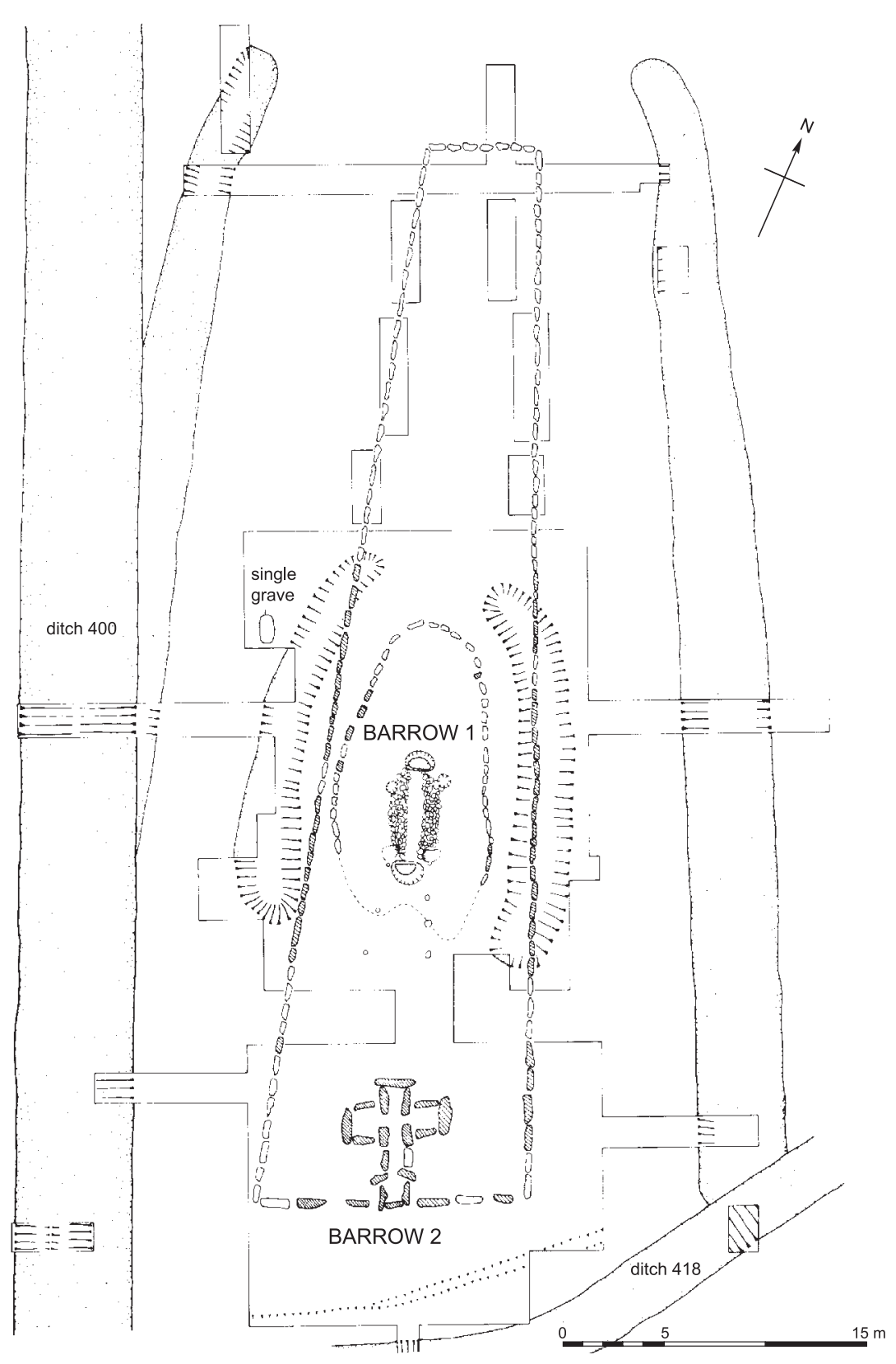

Figure 1. Plan of Wayland's Smithy. was being built, since the two splittrunk posts at either end effectively deny continuing access to the envisaged finished and closed 'mortuary house'. This is certainly implicit in the observation that 'At the time of deposition, the condition of the bodies clearly varied from nearly complete articulation to complete disintegration into individual bones' (Atkinson 1965, 127). In this interpretation of the site, the barrow was built up around the mortuary house immediately after both the latter's construction and the placing of the mortuary deposit within.

Whittle (1991, 93-4; following Kinnes 1975; and Hodder \& Shand 1988; and see Kinnes 1992), on the other hand, preferred an alternative interpretation, where the mortuary structure features represented a 'linear box-like mortuary, perhaps roofed or lidded ...' with a possible sequence of development from an initial shrine defined by the two facing D-shaped posts. In Whittle's reconstruction, successive deposits of human remains, placed directly into the mortuary area over an extended period, were suggested as the most likely process, and the specific nature and relationship of the two rows of 'exposure platform' post holes was left open (Whittle 1991, 71). Eventually the mortuary structure was buried beneath a low mound after '... an interval (perhaps determined by the robustness or otherwise of the timber used and perhaps to be measured in generations) ...' (Whittle 1991, 94). pitched roof, similar to the reconstruction proposed by Ashbee (1966) for Fussell's Lodge. Immediately to the south of the mortuary structure, a double row of small postholes was taken as evidence of a raised exposure platform, where successive cadavers could have been left to decompose (Atkinson 1965, 130).

Although it was not explicitly stated as such by Atkinson (1965), his reconstruction meant that the accumulated human material from the 'exposure platform' had to have been deposited en masse at about the time that the ridge-roofed structure

\section{Wayland's Smithy II}

The mound of Wayland's Smithy II had been set out to follow the same SSE/NNW alignment as the earlier Wayland's Smithy I monument, buried beneath. Like West Kennet, Wayland's Smithy II is exceptional in having a megalithic façade of large, upright sarsens at the entrance to its stone-built chamber, a feature not seen elsewhere in southern England, though it is found in the Clyde and Carlingford cairns of western Scotland and Ireland (Corcoran 1969a, 53; but see also Piggott 
1958, 240, for other possible examples in the Avebury region). The chamber consists of a narrow and partially constricted orthostatic passage, leading to a pair of transepted chambers aligned east-west. This cruciform structure is set into the southern end of a trapezoidal mound, a little short of $55 \mathrm{~m}$ in length, made of chalk, earth and some small amounts of sarsen stones. The perimeter of the mound is defined by a continuous setting of sarsen kerb-stones and the long sides of the monument are flanked by steep-sided, flat-bottomed ditches, from which the bulk of the mound material had been derived (Whittle 1991, 81-4).

\section{The human skeletal remains}

Identification and numbering of human material here follows the scheme presented in Brothwell \& Cullen (1991). The terms 'articulation' and 'articulated' are used in their archaeological sense, referring to bones which, upon excavation, lay in correct anatomical position and spatial association relative to one another, indicating that they were articulated when deposited.

The previously disturbed and ransacked transepted chamber of Wayland's Smithy II was emptied during poorly recorded excavations in 1919-20 (Peers \& Smith 1921); the majority of the excavated human remains removed at that time have since been lost, with the exception of two skulls archived at the Natural History Museum (Whittle 1991, table 3; and see below). The excavations in 1962-3 by Atkinson and Piggott revealed the earlier barrow and recovered from it a substantial, undisturbed, mortuary deposit. A comprehensive, and, for its time, exceptional, bone report (Brothwell \& Cullen 1991), completed c. 1967, was eventually published in Whittle (1991).

While Whittle's (1991) paper remains the definitive account of the monument's excavation, subsequent re-examination of the Wayland's Smithy human skeletal archive by Wysocki and Whittle shows that the original bone report is in need of some revisions (Figs. 2-3). These will be presented in more detail elsewhere (Wysocki \& Whittle in prep.), and a summary of the salient points is presented here:

1. a number of age estimates and sex assessments presented in the original bone report (Brothwell \& Cullen 1991) require adjustment;

2. a small number of individual bones were wrongly identified or mis-sided;

3. a flint projectile tip (probably from a leaf-shaped arrowhead) is embedded in a male innominate (bone group 12, probably the same individual as dated sample 13: see below);
4. none of the human skeletal small-finds given three digit finds numbers (commencing with [00]1, then 155 and culminating with 892) in Brothwell \& Cullen $(1991,72,75)$ are from the Wayland's Smithy I mortuary deposits, as was intimated in that report. The material in fact represents residual human remains excavated in 1962-3 from the west chamber, terminal chamber and passage of Wayland's Smithy II, scatters of human bone from the topsoil, and human material recovered from other contexts.

As a consequence, ideas or conclusions about demography, bone survival rates, burial rites, taphonomy, the nature of the mortuary population and Neolithic perceptions of the monument require re-appraisal. As far as this paper is concerned the following points are significant.

\section{Wayland's Smithy I}

When first exposed, the mortuary deposits, undisturbed since the time of sealing beneath the barrow mound, consisted of a mass of stratified and commingled skeletal material occupying, in broad terms, the central part of the paved mortuary area (strictly speaking this main depositional mass lay just to the north of centre). The northern end of the mortuary floor was occupied by a single, discrete, articulated inhumation (bone group PB/WS1) ${ }^{1}$ in crouched posture, skull to the south, nether regions virtually abutting the flat facade of the D-shaped post marking the northern limit of the mortuary area. The southern half of the mortuary area was empty. Both northern and southern margins of the central mortuary deposits are sharply defined, with minimal overspill, suggesting the existence at the time of deposition of some kind of barrier or spatial demarcation (see Whittle 1991, figs. 5, 7; pls. 8a, 9a, 11a).

The minimum number of individuals represented by the remains in the Wayland's Smithy I mortuary structure is 14; this is also very likely the absolute number of individuals. Eleven males, two females and a child, in various states of completeness, are consistently represented by both cranial and postcranial remains and demographic indicators. A number of individuals (e.g. bone groups PB/WS1, PB/WS2, PB/WS7, PB/WS11) are largely complete and their surviving skeletal parts can be re-assembled. High frequencies of vertebrae and small bones of the hand and foot, as well as a few hyoid bones, and anatomical associations, indicate that these four, at the very least, were deposited as fleshed or only partially decomposed corpses, and it is highly likely that the majority of other individuals were also deposited in similar condition even though lost associations, displacement and missing or incomplete bones 


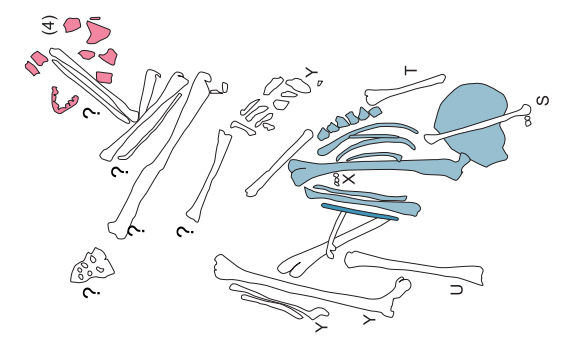

+
+
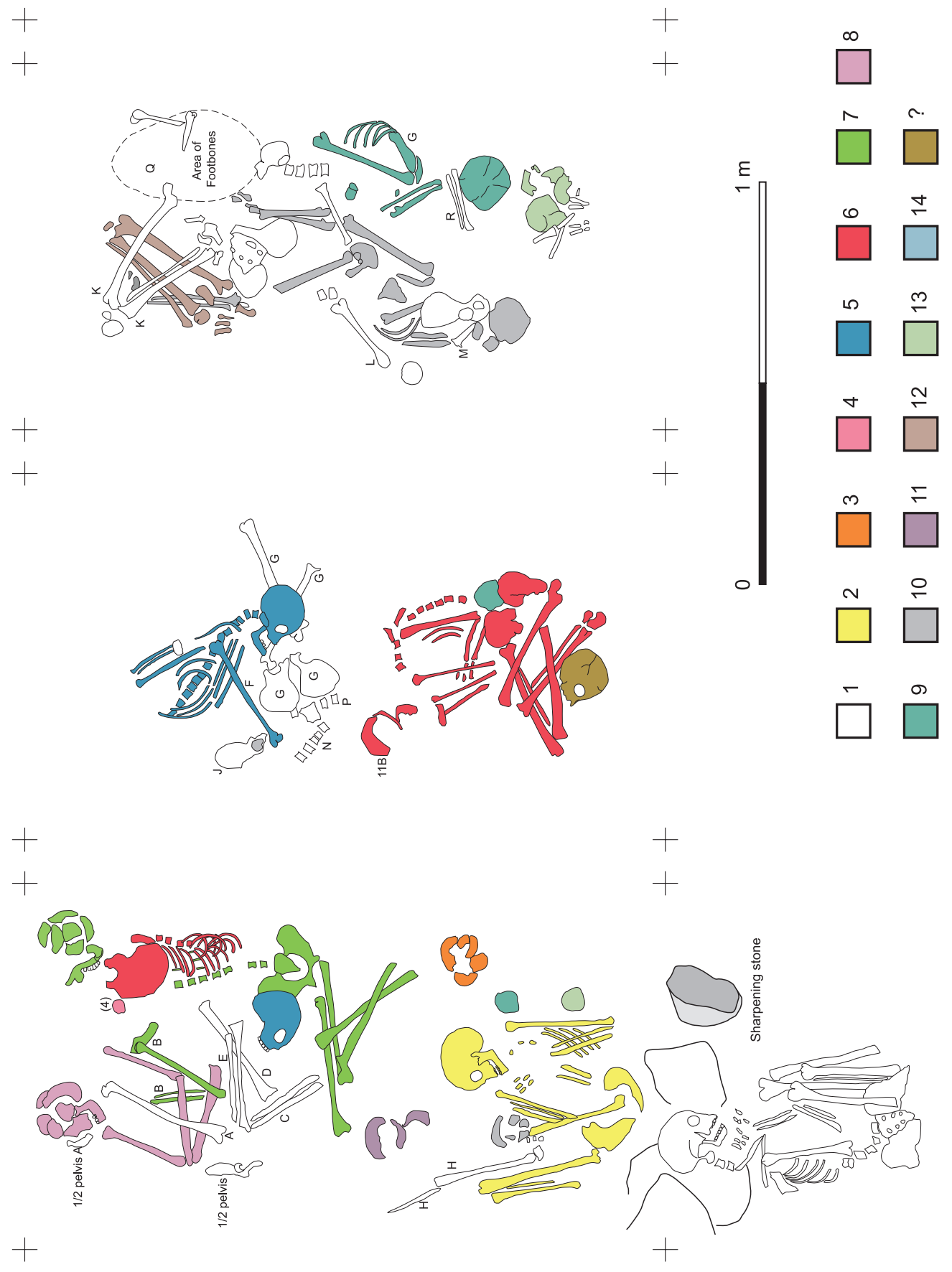

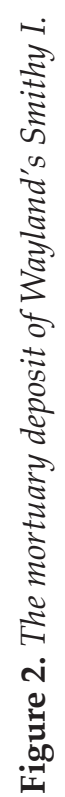


make this point difficult to demonstrate conclusively (cf. Mays 1998, 26-31).

It appears that a number of individuals were piled one on top of another; many of the skeletal remains overlap in a complex, intermingled, stratigraphy that was excavated as four layers (Fig. 2). It should be stressed, however, that these 'layers' are artefacts of the excavation process and can serve to complicate as much as clarify the taphonomy of Wayland's Smithy I; fundamentally the 'layers' represent the phased order in which skeletal elements were lifted. Thus, while some skeletal parts overlay one another in stratigraphic order commensurate with layer number, various other elements assigned to the top, second and third 'layers' were in fact basal deposits or individual specimens that were in contact with the sarsen floor. Equally, overlapping elements from the same discrete individual are dispersed between different 'layers' and assigned to various bone groups. As a result, some spatial and anatomical associations of individual elements have been lost or obscured.

There has also been displacement horizontally and vertically throughout the assemblage, both of individual and grouped bones, through the interaction of various agencies such as gravity, voids created by the decomposition of soft tissues, disturbance from successive deposition, and the slump and settling of overlying barrow material, all of these creating further confusion. For example, individual PB/WS7 (a young adult male) is largely represented by skeletal parts adjacent to the west margin of the mortuary area, but his disarticulated right upper limb was located some $30-40 \mathrm{~cm}$ to the east and was assigned to discrete group B in the original report (in Figure 2, presented here, this has been corrected and the upper limb bones colour-coded as PB/WS7).

The remains of the child, however, are incomplete and were found somewhat scattered and dispersed throughout the assemblage (see Wysocki \& Whittle in prep.). Some of the small unfused epiphyses are present, suggesting that this individual may have been partially articulated when deposited or that at the very least some connective tissue and cartilage were still intact. Dispersal in this instance could be because originally articulated parts were scattered or tossed aside as further individuals were deposited, but it is equally if not perhaps more likely that this individual was already largely disarticulated when placed in the mortuary area. Furthermore, two individuals, a male (contra Brothwell \& Cullen 1991) represented by a pelvic girdle and pair of femora designated group $G$, and a second male represented by a pair of femora (group C), were certainly already incomplete, at least partially dismembered and scavenged by canids when deposited. In the case of the individual represented by group $\mathrm{C}$, canid scavenging may have taken place with the remnants of the corpse already in an advanced state of decomposition/skeletonization and disarticulation when deposited in the mortuary area (see Wysocki \& Whittle in prep.).

A number of bones display varying degrees of geochemical erosion, those from the basal layers being the most heavily eroded, and many individual elements are also fragmentary and/or incomplete. It seems very likely therefore that some missing bones are the result of destructive geochemical and pressureloading processes operating within the mortuary area over time; some missing bones are presumably the result of canid scavenging of a limited number of individuals and some are analytically absent, inasmuch as severe fragmentation and erosion have rendered them unidentifiable.

Three leaf-shaped flint arrowheads, with missing tips, were recovered from Wayland's Smithy I (Atkinson 1965, 130), though precise contextual information was never published. Recent enquiries have revealed that details of their locations were recorded on Reading Museum Services accession cards: one from bone group Q (sample ws14), one on the right innominate from bone group 12 (probably sample ws13) and the third from the pelvis of bone group 10 (possibly sample ws15) (Jill Greenaway pers. comm.). Schulting \& Wysocki (2005) have proposed that the defleshed and disarticulated interment frequently encountered in Neolithic collective burials, and occasional evidence of canid scavenging (Whittle \& Wysocki 1998; Schulting \& Wysocki 2005; this paper), may be a consequence of the problems of ensuring rapid recovery of slain individuals from scenes of conflict rather than of formal acts of excarnation and secondary burial. The new evidence of an embedded flint projectile tip, from the ventral surface of the right ilium (innominate) of bone group 12 (the projectile entered through the abdomen; there is no evidence of bone remodelling or healing), may help sustain such arguments. It certainly further calls into the question the once conventional view that flint arrowheads found amongst Neolithic mortuary remains are votive offerings (Green 1980, table IV, lists 136 examples). Although all the material from bone groups associated with the Wayland's Smithy arrowheads, as well as bone groups overlying those contexts, were subject to intense scrutiny, no further evidence of embedded projectile tips was found. As Schulting \& Wysocki (2005) explain, however, the chances of striking arrowheads leaving such unequivocal evidence in ancient bone are fairly low. 
Wayland's Smithy II

Very little can be said about the mortuary deposits in Wayland's Smithy II. The 1919-20 excavations reported by Peers \& Smith (1921) were of dubious quality and their account relates to previously disturbed deposits, subsequently lost.

The majority of extant material now recognized as belonging to the Wayland's Smithy II interments was excavated during the first season's digging in 1962. It was held in archive, each sub-assemblage or bone group packed separately and accompanied by a label with finds number (as reported in Whittle 1991), contextual description, occasional co-ordinates and/ or cutting number, date and, frequently, the finder's name. Full details will be presented elsewhere (Wysocki \& Whittle in prep.), and most of these scraps and fragments have been identified and listed in Brothwell \& Cullen $(1991,75)$. All we can say here is that the chambers contained multiple interments and that males, females and juveniles were represented. We can also note that small bones of the hand and foot constitute some 40 per cent of the residual material recovered from Wayland's Smithy II.

The re-provenancing of these remains offered the very welcome opportunity of dating both phases of mortuary use at the site, the skulls recovered from Wayland's Smithy II in 1919-20 and held at the Natural History Museum being heavily varnished and judged unlikely to yield reliable dates. However, only three sub-assemblages were considered to be securely enough stratified to meet the requirements of this dating programme. Finds 294 and 295 are both labelled undisturbed fill from $N$. corner of $W$. chamber, the material consisting of small cranial and postcranial adult fragments. Find 308 is labelled undisturbed fill from $W$ corner of $W$. chamber, material consisting of cranial fragments, some fragmentary vertebrae, a few parts from the axial skeleton and carpal and tarsal bones. In terms of contents all three assemblages are similar to other examples of residual scraps of human remains, missed by earlier excavators and often recovered in subsequent re-excavations (see Whittle \& Wysocki 1998 and Saville 1979 for example). Other contexts containing scraps of human bone are less secure, labelled variously central passage re-fill, disturbed rubble fill, disturbed fill below topsoil, terminal chamber fill and topsoil.

\section{Objectives}

Further dating at Wayland's Smithy was undertaken to aid in the presentation of this important monument, in the care of English Heritage. Methodological advances in radiocarbon dating and the interpretation of radiocarbon dates which have been made in the last decade or so (Bayliss, Bronk Ramsey et al. this issue) provide the potential to produce much more precise dating for such monuments than was previously possible (Bayliss \& Bronk Ramsey 2004; Bayliss et al. 1997). The reassessment of the human bone assemblage described above also made this research timely.

Specifically, the new dating programme was designed to address the following objectives:

- to establish the date and span of use of the mortuary deposits in Wayland's Smithy I;

- to establish the date of construction of Wayland's Smithy II;

- to clarify the chronological interval between the two monuments;

- to establish the relative position of Wayland's Smithy I and Wayland's Smithy II in the typological sequence of long barrows and long cairns (Corcoran 1969b; Ashbee 1970; Darvill 1982; Saville 1990; Thomas 1991);

- to determine the chronological relationship between Wayland's Smithy II and the transepted chambers at West Kennet.

\section{Previous dating}

The excavations by Atkinson and Piggott showed that some fill had accumulated in the ditches flanking Wayland's Smithy I before the second monument was constructed over them (Whittle 1991, 80). Charcoal from a branch or small trunk recovered from the ditch-silt of Wayland's Smithy I, thought to have been part of the burning episode associated with clearance prior to the construction of the secondary barrow, produced a radiocarbon date of 3890-3120 cal. вC (I-14682; $4770 \pm 130$ вр). The imprecise nature of this single date meant that little more could be said other than that 'both phases can be placed in general terms in the mid 4th millennium вс' (Whittle 1991, 81).

\section{Sampling}

The existing imprecise absolute dating evidence from Wayland's Smithy meant that the simulations of the likely chronology of the monument built to inform the initial selection of samples were based on limited information. For this reason, a preliminary series of fifteen samples was submitted for dating - bones from six individuals buried in Wayland's Smithy I and four individuals buried in Wayland's Smithy II, and five antler samples associated with the construction of the barrow ditches and mounds. Simulation suggested that this was the minimum number of samples 
likely to provide dating of sufficiently high resolution to meet the objectives of the dating programme. Stratigraphic relationships were available to provide a relative chronology for all of these samples, including an internal sequence of interment within the mortuary structure of Wayland's Smithy I.

In fact, the first series of results provided a coherent sequence of dates for the monument, although two significantly early outliers were identified. To resolve outstanding questions raised by this interim model, four samples of human bone from further individuals interred in the mortuary area in Wayland's Smithy I were submitted for dating in 2002.

Unfortunately, shortly after the second series of measurements had been completed, a technical problem was identified with the bone preparation method used in the Oxford Laboratory (Bronk Ramsey et al. 2004a; Bayliss, Bronk Ramsey et al. this issue). The resolution of this problem necessitated submission of a further series of samples.

In all cases, samples which were not likely to be from a secondary context were preferred. Of the fourteen dated individuals from the mortuary structure of Wayland's Smithy I, ten were from individuals whose remains were recovered in an articulated or partially articulated state. These bones are very unlikely to have been deposited more than a few years or so after the death of the individual concerned, or they would have been dispersed (Mant 1987, 71; Haglund 1997; Manhein 1997; Rodriguez 1997; Roksandić 2002). The other four bones dated from Wayland's Smithy I were disarticulated, and so we have no information about how they were deposited in the monument, although on the basis of osteological duplications they were from a further four individuals. Similarly the four dated disarticulated bones from the chambers of Wayland's Smithy II probably also come from distinct individuals (see below). Thus, all specimens were selected to ensure that each dated sample was from a separate individual. This ensures that all dates included in the models are statistically independent (Bronk Ramsey 2001, 357). In addition, sampling locations on individual bones were chosen to avoid any areas showing previous use of consolidant or adhesives.

The other four samples submitted as part of the recent dating programme were fragments of antler pick, derived from the mounds or from the base of ditches, where there is a plausible association between the sample dated and the actual archaeological events of monument construction. The sample of bulk charcoal dated in the 1960s is recorded as a branch or small trunk which was burnt in the clearance episode which immediately pre-dated the construction of the secondary mound and probably derived from part of the vegetation growing over mound I which was burnt in preparation for the construction of mound II.

\section{Results}

Twenty-three radiocarbon results are now available from Wayland's Smithy (Table 1). They come from 18 different human skeletons, four antler picks, and one carbonized branch or small trunk. All are single-entity samples (Ashmore 1999).

The results are conventional radiocarbon ages (Stuiver \& Polach 1977). The calibrated date ranges provided in Table 1 have been calculated using the maximum intercept method (Stuiver \& Reimer 1986): all other distributions are based on the probability method (Stuiver \& Reimer 1993). All results have been calibrated using OxCal (v3.10) (Bronk Ramsey 1995; 1998; 2001) and data from Reimer et al. (2004).

The first sample from Wayland's Smithy was dated by Isotopes Inc. in 1963-4. This was processed and dated by gas proportional counting of carbon dioxide as described by Walton et al. (1961).

The series of samples dated at the Oxford Radiocarbon Accelerator Unit in 2001 and 2002 were processed using the gelatinization protocol described by Bronk Ramsey et al. (2000). Following the discovery in the laboratory of a contamination problem associated with this method, in eleven cases the contaminated material was re-processed, graphitized, and dated, as described by Bronk Ramsey et al. (2004a). These results are denoted by an asterisk in Table 1. All the other samples dated at Oxford were processed using collagen extraction (Law \& Hedges 1989; Hedges et al. 1989), followed by the revised gelatinization and filtration protocol described by Bronk Ramsey et al. (2004a). All samples were dated by AMS as outlined in Bronk Ramsey et al. (2004b).

In addition, four samples of human bone were dated by the Leibniz Labor für Altersbestimmung und Isotopenforschung, Christian-Albrechts Universität, Kiel in 2005. The powdered bone samples were first treated with acetone, rinsed with demineralized water, and subsequently demineralized in hydrochloric acid (1\%) (Grootes et al. 2004). To remove mobile humic acids, the demineralized bone was treated with sodium hydroxide $\left(1 \%\right.$ at $20^{\circ} \mathrm{C}$ for 1 hour), and again with hydrochloric acid $\left(1 \%\right.$ at $20^{\circ} \mathrm{C}$ for 1 hour $)$. Bone gelatin was dissolved overnight in water (at $85^{\circ} \mathrm{C}$ and $\mathrm{pH} 3$ ), filtered through a pre-combusted $0.45 \mu \mathrm{m}$ pore silver filter, and freeze dried. Combustion, graphitization, 
Alasdair Whittle et al.

Table 1. Radiocarbon measurements from Wayland's Smithy long barrow. Results denoted by * have been undertaken on re-purified gelatin (see Bayliss et al. this issue). Results denoted by $\ddagger$ should not be used for dietary analysis: see text.

\begin{tabular}{|c|c|c|c|c|c|c|c|}
\hline $\begin{array}{l}\text { Laboratory } \\
\text { no. }\end{array}$ & Sample no. and material & $\begin{array}{l}\text { Radiocarbon } \\
\text { age (вР) }\end{array}$ & $\begin{array}{l}\delta^{13} \mathrm{C} \\
(\%)\end{array}$ & $\begin{array}{l}\delta^{15} \mathrm{~N} \\
(\%)\end{array}$ & $\begin{array}{l}\text { C:N } \\
\text { ratio }\end{array}$ & $\begin{array}{l}\text { Calibrated date } \\
\text { range }(95 \% \\
\text { confidence) }\end{array}$ & $\begin{array}{l}\text { Posterior density } \\
\text { estimate at } 95 \% \\
\text { probability unless } \\
\text { otherwise stated }\end{array}$ \\
\hline I-1468 & $\begin{array}{l}\text { charcoal, from a branch or small } \\
\text { trunk of carbonized wood some } 4 \mathrm{ft} \\
(1.2 \mathrm{~m}) \text { long, from berm and/or ditch } \\
\text { fill of Wayland's Smithy I, relating } \\
\text { to the clearance of the site before the } \\
\text { construction of Wayland's Smithy II }\end{array}$ & $4770 \pm 130$ & $\begin{array}{l}-25.0 \\
\text { (assumed) }\end{array}$ & - & - & 3890-3120 cal. вс & 3515-3405 cal. BC \\
\hline OxA-13167* & $\begin{array}{l}\text { ws1, red deer (Cervus elaphus) antler } \\
\text { pick (find 828) from base of secondary } \\
\text { ditch in cutting 21, at NW end }\end{array}$ & $4649 \pm 41$ & -21.2 & 6.1 & 3.4 & 3630-3350 cal. вс & $3470-3380 \mathrm{cal} . \mathrm{BC}$ \\
\hline OxA-13244* & $\begin{array}{l}\text { ws2, red deer (Cervus elaphus) antler } \\
\text { pick (find 869) from base of secondary } \\
\text { ditch in cutting 19A, towards NW end }\end{array}$ & $4683 \pm 39$ & -20.4 & 6.3 & 3.1 & 3630-3360 cal. вс & $3470-3385$ cal. вс \\
\hline OxA-13168* & $\begin{array}{l}\text { ws3, red deer (Cervus elaphus) antler } \\
\text { pick (find 632) from chalk rubble over } \\
\text { sarsen kerb of Wayland's Smithy II, in } \\
\text { cutting 5D; chalk rubble represents slip } \\
\text { from the mound of Wayland's Smithy II }\end{array}$ & $4547 \pm 54$ & -22.6 & 4.8 & 3.3 & 3500-3090 cal. вс & $3480-3310 \mathrm{cal}$. вС \\
\hline OxA-13169* & $\begin{array}{l}\text { ws5, red deer (Cervus elaphus) antler } \\
\text { pick (find 778) in dark layer in cutting } \\
8 \text {, interdigitating with stone of primary } \\
\text { construction, and so from mound of } \\
\text { Wayland's Smithy I }\end{array}$ & $4634 \pm 45$ & -21.6 & 4.4 & 3.3 & 3620-3340 cal. вс & $3530-3435 \mathrm{cal}$. BC \\
\hline OxA-13203* & $\begin{array}{l}\text { ws6, human bone, right femur from } \\
\text { adult male, articulated skeleton group } \\
1 \text { in primary mortuary deposit }\end{array}$ & $4749 \pm 38$ & -20.8 & 9.8 & 3.2 & 3640-3370 cal. вс & $3600-3525$ cal. BC \\
\hline OxA-14769 & $\begin{array}{l}\text { ws7, human bone, right femur from } \\
\text { adult male, articulated skeleton group } \\
\text { 2, overlying ws10 in primary mortuary } \\
\text { deposit }\end{array}$ & $4812 \pm 35$ & -20.6 & 10.5 & 3.2 & 3660-3520 cal. вс & $3590-3525$ cal. BC \\
\hline OxA-14770 & $\begin{array}{l}\text { ws8, human bone, right femur from } \\
\text { adult male, partially articulated } \\
\text { skeleton group 7, overlying ws13 in } \\
\text { primary mortuary deposit }\end{array}$ & $4802 \pm 35$ & -20.7 & 10.1 & 3.3 & 3660-3520 cal. вс & 3590-3525 cal. BC \\
\hline OxA-14771 & $\begin{array}{l}\text { ws9, human bone, right femur from } \\
\text { partially articulated adult male } \\
\text { skeleton (bone group G) which shows } \\
\text { clear evidence of carnivore scavenging, } \\
\text { from upper layer of the primary } \\
\text { mortuary deposit; stratigraphically } \\
\text { later than ws16, and earlier than ws8 }\end{array}$ & $4749 \pm 34$ & -20.4 & 10.3 & 3.2 & 3640-3370 cal. вс & $\begin{array}{l}3605-3550 \text { cal. } \text { BC } \\
(84 \%) \text { or } 3545-3525 \\
\text { cal. } \text { вC }(11 \%)\end{array}$ \\
\hline OxA-14772 & $\begin{array}{l}\text { ws10, human bone, right femur from } \\
\text { adult male, partially articulated } \\
\text { skeleton group } 11 \text { in primary mortuary } \\
\text { deposit }\end{array}$ & $4787 \pm 34$ & -20.8 & 9.9 & 3.3 & 3650-3510 cal. вс & $3595-3525$ cal. вС \\
\hline OxA-13175* & $\begin{array}{l}\text { ws11, human bone, right femur from a } \\
\text { partially articulated adult ?male (bone } \\
\text { group W), from the basal layer of the } \\
\text { primary mortuary deposit, lying on the } \\
\text { stone paving }\end{array}$ & $4717 \pm 45$ & -20.7 & 9.3 & 3.2 & 3640-3360 cal. вс & $\begin{array}{l}3605-3550 \text { cal. } \text { BC } \\
(84 \%) \text { or } 3545-3525 \\
\text { cal. } \text { вС }(11 \%)\end{array}$ \\
\hline KIA-27623 & $\begin{array}{l}\text { ws12, human bone, right femur } \\
\text { from adult male, from bone group } \\
\text { F, in second to top layer of primary } \\
\text { mortuary deposit }\end{array}$ & $4750 \pm 32$ & $-10.7 \ddagger$ & - & - & 3640-3370 cal. вс & $3600-3525$ cal. BC \\
\hline
\end{tabular}


Table 1. (cont.)

\begin{tabular}{|c|c|c|c|c|c|c|c|}
\hline $\begin{array}{l}\text { Laboratory } \\
\text { no. }\end{array}$ & Sample no. and material & \begin{tabular}{|l|} 
Radiocarbon \\
age (вР)
\end{tabular} & \begin{tabular}{|l|}
$\delta^{13} \mathrm{C}$ \\
$(\%)$
\end{tabular} & $\begin{array}{l}\delta^{15} \mathrm{~N} \\
(\%)\end{array}$ & $\begin{array}{l}\text { C:N } \\
\text { ratio }\end{array}$ & $\begin{array}{l}\text { Calibrated date } \\
\text { range }(95 \% \\
\text { confidence) }\end{array}$ & $\begin{array}{l}\text { Posterior density } \\
\text { estimate at } 95 \% \\
\text { probability unless } \\
\text { otherwise stated }\end{array}$ \\
\hline OxA-13170* & $\begin{array}{l}\text { ws13, human bone, right femur from } \\
\text { adult male, partially articulated } \\
\text { skeleton group K, overlying ws16, in } \\
\text { primary mortuary deposit }\end{array}$ & $4791 \pm 40$ & -20.4 & 10.4 & 3.4 & $3650-3380$ cal. вс & $3595-3525 \mathrm{cal}$. BC \\
\hline KIA-27624 ${ }^{3}$ & $\begin{array}{l}\text { ws14, human bone, right femur from } \\
\text { adult, possibly female (no articulation } \\
\text { demonstrable), from bone group Q } \\
\text { in third layer of primary mortuary } \\
\text { deposit }\end{array}$ & $4779 \pm 40$ & $-25.7 \ddagger$ & - & - & 3650-3380 cal. вс & 3600-3525 cal. BC \\
\hline KIA-27625 & $\begin{array}{l}\text { ws15, human bone, right femur } \\
\text { from adult male (possibly with some } \\
\text { apposition), in bone group V, in basal } \\
\text { layer of primary mortuary deposit }\end{array}$ & $4713 \pm 37$ & $-22.7 \ddagger$ & - & - & 3640-3370 cal. вс & $\begin{array}{l}3600-3550 \mathrm{cal} . \text { BC } \\
(84 \%) \text { or } 3545-3525 \\
\text { cal. } \text { BC }(11 \%)\end{array}$ \\
\hline OxA-14471 & $\begin{array}{l}\text { ws16, human bone, right femur } \\
\text { from adult male, with long bones } \\
\text { in apposition from group } \alpha ; \\
\text { stratigraphically earlier than ws13 }\end{array}$ & $4808 \pm 38$ & -20.9 & 10.1 & 3.2 & 3660-3520 cal. вс & 3595-3525 cal. BC \\
\hline OxA-13330 & $\begin{array}{l}\text { ws17, human bone, disarticulated } \\
\text { right femur from adult male (bone } \\
\text { group C), which shows clear evidence } \\
\text { of carnivore scavenging, from } \\
\text { upper layer of the primary deposit, } \\
\text { stratigraphically later than ws9 }\end{array}$ & $4817 \pm 39$ & -20.8 & 9.8 & 3.2 & $3660-3520$ cal. вс & 3595-3525 cal. вс \\
\hline KIA-27626 & $\begin{array}{l}\text { ws18, human bone, left humerus } \\
\text { from an adult, probably female, from } \\
\text { partially articulated bone group PB } 8 \\
\text { in upper layer of primary mortuary } \\
\text { deposit }\end{array}$ & $4714 \pm 36$ & $-18.7 \ddagger$ & - & - & $3640-3370$ cal. вс & 3590-3520 cal. вс \\
\hline OxA-13176* & $\begin{array}{l}\text { ws19, human bone, right femur from a } \\
\text { probably originally partially articulated } \\
\text { skeleton of a child, from the primary } \\
\text { mortuary deposit, mainly among the } \\
\text { material bone group PB } 5 \text { overlying } \\
\text { ws13 and ws16; other material from } \\
\text { north end of deposit and on stone } \\
\text { paving }\end{array}$ & $4809 \pm 44$ & -20.8 & 10.4 & 3.2 & 3650-3380 cal. вс & 3590-3525 cal. вс \\
\hline OxA-13171* & $\begin{array}{l}\text { ws20, human bone, disarticulated adult } \\
\text { left metatarsal V from west corner of } \\
\text { Wayland's Smithy II west chamber }\end{array}$ & $4761 \pm 41$ & -20.9 & 10.1 & 3.3 & 3650-3370 cal. вс & 3430-3370 cal. BC \\
\hline OxA-13245* & $\begin{array}{l}\text { ws21, human bone, disarticulated adult } \\
\text { right metatarsal V from west corner of } \\
\text { Wayland's Smithy II west chamber }\end{array}$ & $4770 \pm 38$ & -20.8 & 10.4 & 3.1 & 3650-3380 cal. вс & 3430-3375 cal. BC \\
\hline OxA-13246* & $\begin{array}{l}\text { ws22, human bone, disarticulated adult } \\
\text { left metatarsal V from west corner of } \\
\text { Wayland's Smithy II terminal chamber }\end{array}$ & $4603 \pm 35$ & -21.2 & 11.4 & 3.3 & 3500-3190 cal. вс & 3450-3335 cal. вс \\
\hline OxA-13325 & $\begin{array}{l}\text { ws } 23 \text {, human bone, disarticulated adult } \\
\text { right metatarsal V from north corner of } \\
\text { Wayland's Smithy II west chamber }\end{array}$ & $4707 \pm 40$ & -20.4 & 9.9 & 3.1 & 3640-3360 cal. вс & 3435-3365 cal. BC \\
\hline
\end{tabular}

and measurement procedures were those described by Nadeau et al. (1997; 1998). For sample KIA-27624, ws14, the insoluble organic residue on the filter was sufficient to be dated separately as a check on the degree of sample contamination. ${ }^{13} \mathrm{C} /{ }^{12} \mathrm{C}$ ratios were measured by the AMS system simultaneously with the ${ }^{14} \mathrm{C} /{ }^{12} \mathrm{C}$ ratio and used to correct this ratio for isotopic fractionation (following Stuiver \& Polach 1977). These measurements are denoted by a $\ddagger$ in Table 1 and should not be used for dietary analysis. 


\section{Interpretations}

Four alternative chronological models for Wayland's Smithy are discussed here. The differences between these models relate in essence to varying archaeological interpretations of the structural sequence and use of Wayland's Smithy II. Our approach to modelling the chronology of Wayland's Smithy I is identical in all four models, and the differences in the resultant posterior density estimates for that part of the monument are trivial.

A summary of the relative sequence of the deposition of identified individuals from Wayland's Smithy I is set out in Figure 3. In building a sequence for the primary mortuary deposit, the procedure relies not only on the observation of vertical and horizontal stratigraphic relationships but also on the assignment of particular bones to particular individuals. We have not been able to reconstruct all the skeletons nor assign all bones and fragments to specific individuals with a similar degree of certainty, or in some cases with any certainty at all. As a result it is not possible to build a single sequence for all 14 individuals. This is further complicated because some individuals are stratigraphically isolated (e.g. articulated skeleton bone groups $\mathrm{PB} / \mathrm{WS} 1, \mathrm{~PB} / \mathrm{WS} 2)$. For example, in the case of PB/WS1 (dating sample ws6), intuitively we would expect this to be the last interment. However, this adult male was placed on the floor of the mortuary structure, to the north of the main mass of mortuary deposits without other remains below or above him, and so could have been interred at any time in the depositional sequence. All the models described below are insensitive to the precise reading of the depositional sequence of this individual.

We were, however, able to identify samples that discriminated all 14 individuals, and working with transparent overlays of the four layers, copied in 1986 from the original plans drawn up by Richard Atkinson, were able to offer shorter secure stratigraphical sequences. Because of the relative articulation of most of the individuals represented, we believe that order of deposition probably reflects order of death.

Samples ws16 (bone group $\alpha$ ), ws11 (bone group $\mathrm{W})$ and ws15 are adult male right femora from basal deposits. Both ws16 and ws11 were in direct contact with the sarsen paving, and both specimens are of sufficient size and from areas of sufficiently dense accumulations of bone to preclude them having fallen through from later deposits after disarticulation. Adult male right femur sample ws13 (bone group K) is later than sample ws16 as it directly overlies material which directly overlies ws16. It is part of a group of bones which consists of an articulated right lower limb and is therefore not from an individual who died a significantly lengthy time before deposition. It is also very likely later than sample ws11, because it overlies material which overlies basal deposits, although it does not have any direct vertical stratigraphic association with sample ws11. Sample ws13 is in turn overlain by parts of the articulated skeleton represented by sample ws8, and by parts of the child from which ws19 was taken (for which see below). Sample ws15 was also in direct contact with the sarsen paving, but was from the eastern periphery of the central bone group and could have been displaced from a deposit stratigraphically later than ws16 and ws11. It was, however, overlain by ws10, ws12 (bone group F) and ws17 (bone group C).

Sample ws14 is also basal, but is an incomplete right femur from the southwest periphery of the central mass of bones. It is not directly overlain by any of the other samples and could have been displaced from a later deposit. Its place in the depositional sequence is therefore uncertain.

Male right femur ws10 (part of articulated skeleton bone group PB/WS11) is later than ws11 as it directly overlies material which directly overlies ws11. Its stratigraphic relationship to ws13 is unclear, but it too is certainly later than ws16. It is directly overlain by sample ws7 (articulated skeleton bone group PB/WS2).

Sample ws9 (bone group G) is later than ws16 and ws11, but its stratigraphic relationship to ws13 is also uncertain. It is overlain by ws8 (part of articulated skeleton bone group PB/WS7). Sample ws9 is also overlain by ws17 (bone Group C). However, group C consists of a pair of heavily canid-scavenged disarticulated femora and could potentially be from an individual who died earlier than the individuals stratigraphically below him. This relationship has therefore not been incorporated in the models. Parts of the articulated individual PB/WS7, from which ws8 is drawn, overlie ws13.

Sample ws12 (bone group F) overlies ws9, ws13, ws16 and ws11, and is overlain by ws17, but it is from a bone group represented by only one bone and so could have been deposited at any point within the Wayland's Smithy I sequence; for that reason it is not shown in the matrix of relationships on Figure 3. Sample ws18, a female left humerus (bone group 8), is from the uppermost layer and overlies ws8, ws9, ws13 and ws16.

Sample ws6 is from the northernmost discrete articulated inhumation PB/WS1, who, as noted above, could have been placed at any time in the depositional 
sequence, although we might well expect him to be the final deposit. Sample ws19 is a right femur from the single child in the mortuary group. It was located among material from bone group PB5, which overlies both ws13 and ws16. However, as noted above, the remains of this individual were somewhat dispersed. Bone group PB5 is from the southern part of the main depositional mass. Other bones from this child were located close to the northern margins of the deposit, a few centrally, and many were directly in contact with the paved flooring. As noted earlier, the presence of a number of small unfused epiphyses strongly suggests that this individual was at least partially articulated when deposited.

Although we are confident that we have dated all the individuals whose remains were interred in Wayland's Smithy I, there is less certainty about the dates of individuals potentially slain by arrowheads. In the case of the arrowhead associated with group $Q$, we do not know with which bone it was in direct association (the contextual information is simply 'with bone group $\left.Q^{\prime}\right)$. As noted above, all the material from this group was subject to intense examination for further traces of projectile injury but none was found. The material from bone group Q is overlain by both PB6 and PB7 and it is possible that the arrowhead could have been lodged in either of these individuals and fell through to bone group $\mathrm{Q}$ following decomposition. Furthermore, bone group $Q$ consists of the remains of at least two individuals: a probable female and a male.

The arrowhead with bone group 10 is also problematic. The contextual information states that the projectile was found 'with the pelvis', but there is no direct evidence to show that any of the bones in this group had actually been subject to projectile trauma, and it is possible that in this case too the arrowhead has fallen out of an overlying corpse. However, as noted above and elsewhere (Schulting \& Wysocki 2005), the chance of a flint arrowhead actually striking bone and leaving diagnostic evidence is low, with an expected frequency of about $25 \%$. Bone group 10 includes a pair of male innominates (part of the pelvis) and a left male femur. Assuming that the associated arrowhead did strike this individual, dated specimen ws15 (male right femur, bone group V) is, on morphometric and spatial grounds, the most likely to belong to this individual.
The flint arrowhead tip is embedded in the right innominate from bone group 12 and the third leaf-shaped arrowhead was found in direct association with this bone. Dated sample ws13 (male right femur, bone group $\mathrm{K}$ ) is on morphometric and spatial grounds the most likely to belong to this individual.

After the people were interred in the mortuary structure of Wayland's Smithy I, it seems likely that a mound was constructed over it. It is not in fact easy to distinguish the limits of the mound of Wayland's Smithy I from that of Wayland's Smithy II in the available cross-sections (Whittle 1991, fig. 6), and Whittle $(1991,68)$ even questioned briefly whether a mound existed at all in the first phase of the monument. Given the existence of both the flanking ditches and the ovalshaped kerb of Wayland's Smithy I, however, it seems economical to suppose that there was a low mound of some kind within kerb and ditches. It also seems sensible to envisage that this was not constructed until the use of the primary mortuary structure had ended. A succession of depositions is likely, most probably inserted from above rather than from one or other end of the mortuary structure because of its very limited width, and we have argued above that the mortuary structure was more probably some kind of long, narrow, lidded box rather than a closed tent-like affair capable of bearing the load of a mound. This means that further human remains could not have been deposited within the mortuary structure once the mound had been raised. Sample ws5 is a piece of an antler pick from a dark layer in contact with the stone of the primary mortuary structure and has been interpreted 
as the remains of a tool used in the construction of the mound over Wayland's Smithy I.

After the first mound had been built, a period of disuse ensued. This is seen in primary, and a limited amount of secondary, silting in the ditches of the first monument, and in the charcoal over the berm and infilling ditches, especially on the east side, of Wayland's Smithy I, which is interpreted as resulting from re-clearance of vegetation which had had time to grow over the monument (Whittle 1991, 80; Atkinson $1965,132)$.

\section{The preferred model}

A chronological model for Wayland's Smithy, incorporating the site sequence preferred in Whittle (1991), is shown in Figure 4. In this model, it is assumed that Wayland's Smithy II was a unitary construction, with mound, kerb and chambers built all at more or less the same time. On this basis, there are three radiocarbon dates which are associated with this construction episode. Samples ws1 and ws2 are fragments of antler tools found on the base of the secondary ditch at the NW end. A third fragment of antler pick, ws5, was recovered from chalk rubble over the secondary kerb on the east side of the monument. We initially interpreted this deposit as slip from mound II, and thus all three samples should represent tools used in the construction of the second phase of the monument. Although all three samples produced statistically consistent radiocarbon measurements $\left(T^{\prime}=4.2 ; T^{\prime}(5 \%)\right.$ $=6.0 ; v=2$ : Ward \& Wilson 1978), the chronological model which includes this interpretation has poor overall agreement $\left(\mathrm{A}_{\text {overall }}=40.8 \%\right)$. This is because of the poor individual agreement for OxA-13168 (ws5; A $=15.4 \%$ ), which appears to be later. A revised version of the model, that shown in Figure 4, incorporates the interpretation subsequently made that ws5 came from an episode of addition or maintenance later than the secondary construction itself. In fact, the posterior density estimates derived by variants of the model incorporating these different interpretations of the taphonomy of ws5 are virtually identical, and the overall model is insensitive to this archaeological detail.

For the contents of the chambers of Wayland's Smithy II, the very fragmentary nature of the material has inevitably constrained sample selection. A left (ws20) and a right (ws21) metatarsal V, of sufficiently different sizes to indicate two individuals, have been selected from sub-assemblage 308 (W corner of W chamber). A right metatarsal $\mathrm{V}$ (ws23) from subassemblage 294 ( $\mathrm{N}$ corner of $\mathrm{W}$ chamber), which is again incommensurate with the left metatarsal $V$ from
308 , very likely represents a third individual. Finally, a left metatarsal V (ws22) from sub-assemblage 307 (terminal chamber filling) was also selected. While one cannot say with absolute certainty that it does not belong with either of the two right metatarsals on osteological grounds, its location makes such an association less likely. The four specimens must represent at least three individuals and probably represent four individuals. A similar level of discrimination is not possible with any of the other material still available from Wayland's Smithy II. In the model shown in Figure 4, these remains from Wayland's Smithy II are assumed to be from people interred directly into its chambers. Such an assumption accords well with the demonstrable absence of ancestral remains from Wayland's Smithy I, although that comparison does not of course by itself provide any certainty on the issue.

The chronological model shown in Figure 4 has good overall agreement $\left(A_{\text {overall }}=65.8 \%\right)$, suggesting that the radiocarbon dates do not contradict the reading of the monument sequence proposed by Whittle (1991). This model suggests that the first inhumations were placed in the mortuary structure of Wayland's Smithy I in 3610-3550 cal. BC (83\% probability) or 3545-3525 cal. вС (12\% probability; start Wayland's Smithy I: Fig. 4) or 3590-3555 cal. вС (67\% probability) or 3540-3535 cal. вС (1\% probability). Human remains ceased to be placed in the chamber in 3590-3520 cal. BC (95\% probability; end Wayland's Smithy I) or 3580-3550 cal. BC (62\% probability) or 3535-3530 cal. BC (6\% probability). Burial continued in the mortuary structure for between 1 and 65 years (95\% probability; use Wayland's Smithy I: Fig. 5), probably for only $1-15$ years $(68 \%$ probability) - less than a single generation!

The mound was thrown up over this mortuary structure in 3530-3435 cal. вС (95\% probability; OxA13169: Fig. 4), probably in 3520-3470 cal. вС $(68 \%$ probability). There was a gap preceding the mound of between 5 and 130 years (95\% probability; mortuary structure \& mound I: Fig. 5), probably of 40-100 years (68\% probability).

After the construction of the primary mound, a second period of disuse ensued, lasting 1-75 years (95\% probability; I \& II: Fig. 5), probably for $1-35$ years (68\% probability).

The burning episode that cleared the site of encroaching vegetation then occurred before the unitary construction of Wayland's Smithy II, which took place in 3490-3390 cal. BC (95\% probability; start Wayland's Smithy II: Fig. 4), probably in 3460-3400 cal. вс (68\% probability). On the basis of the limited data available, the use of this monument ended in 3430-3265 cal. вС (95\% probability; end Wayland's Smithy II), probably 
in the middle decades of the thirtyfourth century cal. вс (Fig. 4). This barrow was in use for between 1-185 years (95\% probability; use Wayland's Smithy II: Fig. 5), probably for 4-125 years (68\% probability).

A minor variant on this model, which allows the possibility that the chambers and kerb of Wayland's Smithy II may have been free-standing for a while prior to construction of the secondary barrow, on the analogy of the Fussell's Lodge long barrow (Ashbee 1966, 30; Wysocki et al. this issue), provides posterior density estimates which are practically identical to those produced by the model shown in Figure 4. This model is therefore not further reported in detail here.

A third variant model develops the idea that the chambers and kerb may have formed a free-standing phase of construction. This model incorporates the interpretation that the raising of the second mound formed the closing event of the monument, and so post-dates all the human remains found in the transepted chambers. This would find parallels in those other instances where mounds or cairns can be seen as closing events, though the continuing accessibility of the chambers from the façade of Wayland's Smithy II may make such a claim at this site less plausible. This model has poor overall agreement $\left(\mathrm{A}_{\text {overall }}=53.5 \%\right)$, because it is unlikely that all the dated individuals buried in the transepted chambers died before the barrow was constructed. Given the nature of the architecture of this phase, it is not unexpected at all that people could be interred in the accessible chambers after the monument had been constructed. This model is therefore not shown here.

Figure 5. Probability distributions of the number of years during which various activities occurred at Wayland's Smithy, derived from the model shown in Figure 4.

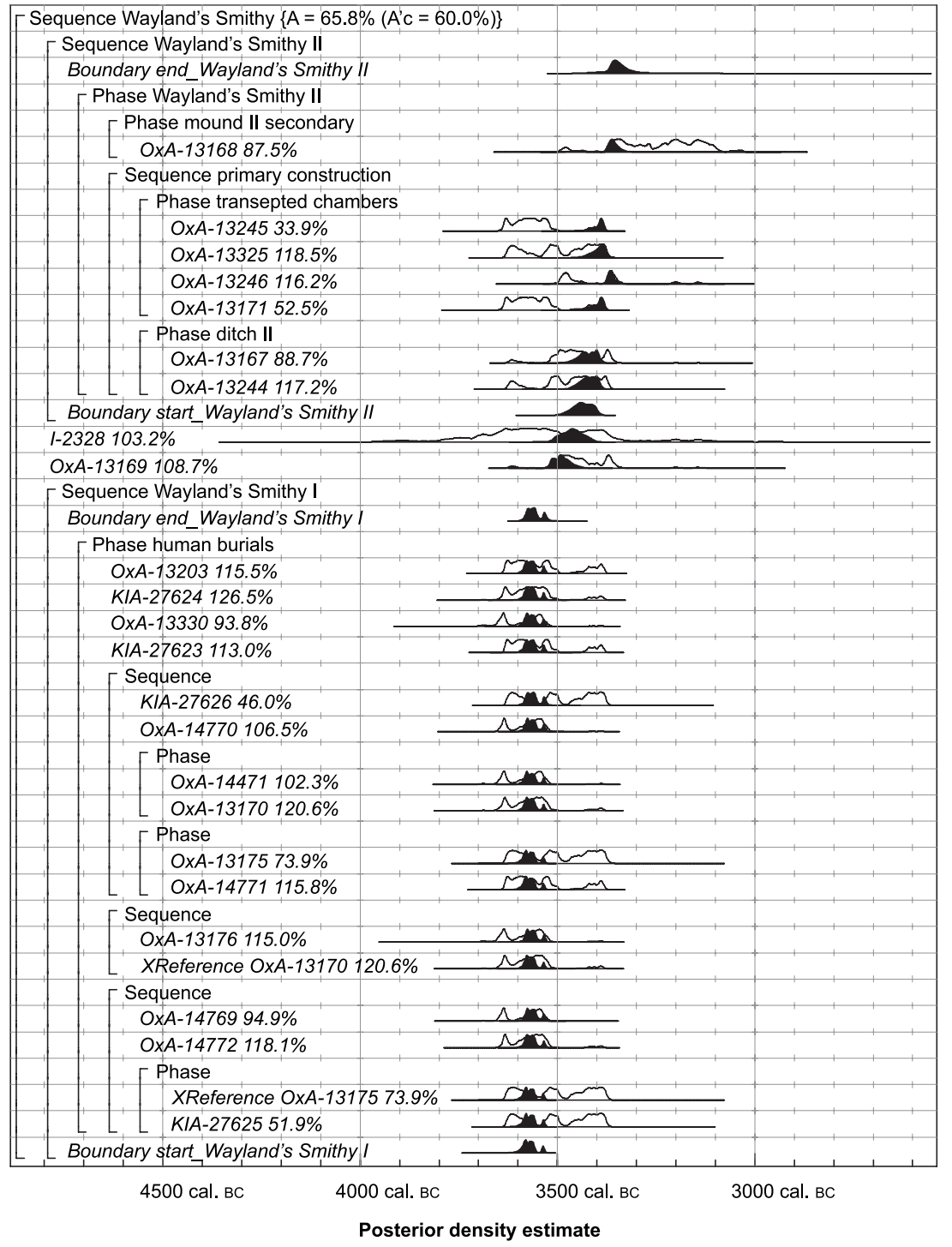

Figure 4. Probability distributions of dates from Wayland's Smithy. Each distribution represents the relative probability that an event occurs at a particular time. For each radiocarbon date, two distributions have been plotted: one in outline which is the result of simple radiocarbon calibration, and a solid one based on the chronological model used; the 'event' associated with, for example, KIA-67525, is the growth of the person whose bones were dated. The other distributions correspond to aspects of the model. For example, the distribution 'start Wayland's Smithy I' is the posterior density estimate for the first burial activity on this site The large square brackets down the left-hand side and the OxCal keywords define the overall model exactly.

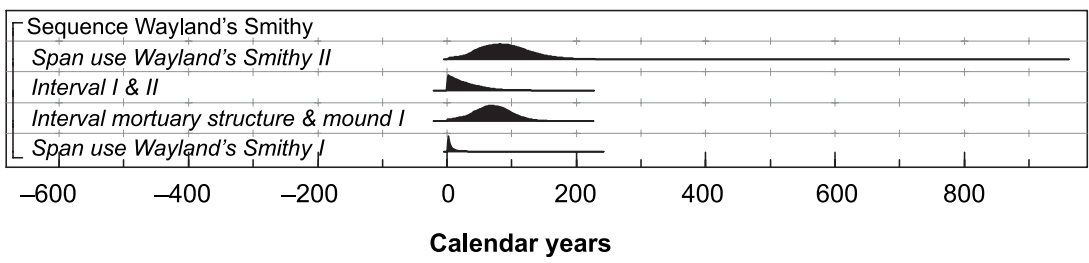




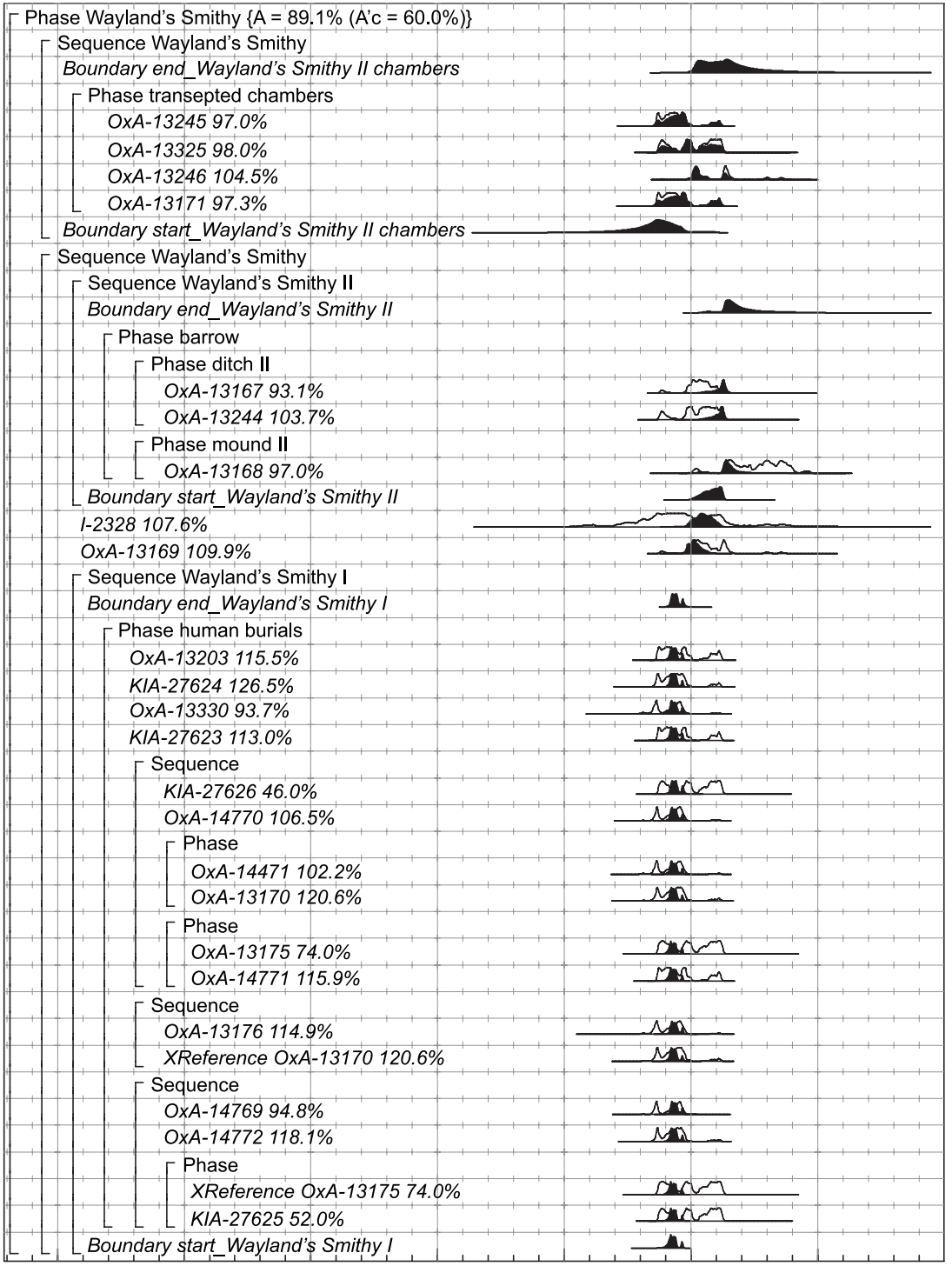

$6000 \mathrm{cal}$. BC $5500 \mathrm{cal}$. BC $5000 \mathrm{cal}$. BC $4500 \mathrm{cal}$. BC $4000 \mathrm{cal}$. BC $3500 \mathrm{cal}$. BC $3000 \mathrm{cal}$. BC

Posterior density estimate

Figure 6. Probability distributions of dates from Wayland's Smithy, according to the alternative archaeological reading where the transepted chambers of Wayland's Smithy II could have been constructed at any time during the sequence of the monument. The format is identical to that for Figure 4. The large square brackets down the left-hand side and the OxCal keywords define the overall model exactly.

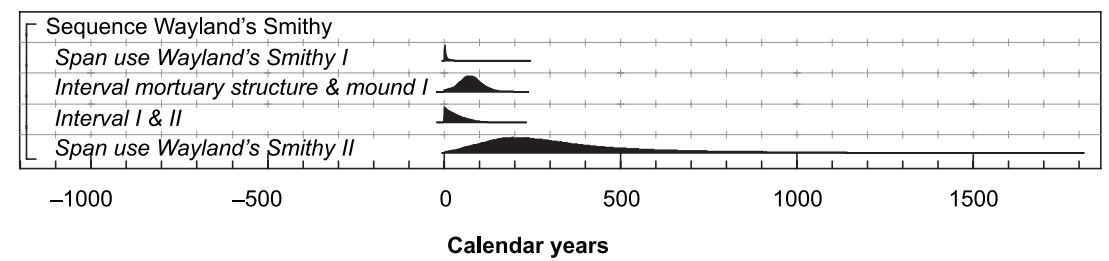

In the fourth model, the sequence of Wayland's Smithy I is treated in the same way as before but the chambers are envisaged as coming anywhere in the overall sequence, possibly earlier than Wayland's Smithy I but more feasibly contemporary or overlapping with it. In this case, the orthostatic chambers of Wayland's Smithy II could have stood at the same time as the mortuary structure of Wayland's Smithy I was in use, and on the same alignment. Given the lack of direct stratigraphic relationship between the transepted chambers and the monument of Wayland's Smithy I, this is a theoretically possible sequence. Analogies for this could be found elsewhere, for example in southwest and northeast Scotland, where linear settings of smaller structures were later incorporated into a single monument, and a similar idea might be seen as being part of the layout of those Cotswold monuments with multiple lateral chambers.

The posterior density estimates for the dates of construction of different parts of the monument overall provided by this model (Figs. 6-7) are very similar to those given by the previous models discussed. It can be seen, however, that the chronology of the human remains within this context is very poorly known, if based on the results of the four disarticulated bone samples from the transepted chambers alone. The model estimates that the start of these deposits was in 3995-3390 cal. BC (95\% probability; start_Wayland's Smithy II chambers: Fig. 6), probably in 3725-3530 cal. $B$ С (68\% probability), and the end was in 3515-2960 cal. BC (95\% probability; end_Wayland's Smithy II chambers: Fig. 6), probably in 3490-3295 cal. BC

Figure 7. Probability distributions of the number of years during which various activities occurred at Wayland's Smithy, derived from the model shown in Figure 6. 
(68\% probability). The long tails on these distributions provide realistic estimates for the uncertainty in our knowledge of the chronology of this activity. It is salutary to reflect how much of our understanding of the sequence of the earlier Neolithic in Britain is currently based on sites dated in a comparable fashion! On a more optimistic note, the results from this model, imprecise though they may be, do allow that this interpretation regarding the relative position of the Wayland's Smithy II chambers may be true, that is, that they could have been constructed and used at the same time as Wayland's Smithy I.

Overall, however, though model 4 is possible and plausible, we prefer model 1. Regrettably, there is now no more available dating material from Wayland's Smithy II and this ends as a matter of archaeological interpretation and judgment. We think that model 1 best catches what we understand of the development of Wayland's Smithy, though other interpretations remain open. We go on finally now to discuss wider implications.

\section{Discussion}

This dating programme shakes our familiarity with the Wayland's Smithy long barrow. The reputation of the excavators on the one hand and the frequent citation of the monument, especially the mortuary deposits in Wayland's Smithy I, conspire together to encourage the view that we understand what went on there; this was a place of collective burial, perhaps involving predominantly successive rites, and of progressive monumentalization. While these characterizations may be true, or partly so, they have been seen, over and over again, in a timeless vacuum, belonging somewhere in a period lasting centuries.

We now have to confront a much more precise chronology, which raises fresh questions and underlines how much we do not know about this remarkable monument. Far from being a site which we can use for timeless discussion of mortuary rites and monumentalization in the early Neolithic in general, the results presented above make it striking how late the start of the sequence at Wayland's Smithy really is. The mortuary structure of Wayland's Smithy I was not the first activity to take place on this site, as seen in the evidence for earlier occupation (Whittle 1991), but compared with what had already happened not far away elsewhere in the thirty-eighth and thirtyseventh centuries cal. вс, the situation at Wayland's Smithy from the thirty-sixth into the thirty-fifth or thirty-fourth centuries cal. вс may appear now rather unusual. By the time the first people were deposited in Wayland's Smithy I, probably in the earlier thirtysixth century cal. BC, other long cairns and barrows were already old and had indeed been largely finished with: witness the other sites reported in this series, Ascott-under-Wychwood, Hazleton, West Kennet and Fussell's Lodge (Bayliss, Bronk Ramsey et al. this issue; Meadows et al. this issue; Bayliss, Whittle \& Wysocki this issue; Wysocki et al. this issue). The wooden box at Haddenham, with which the mortuary structure of Wayland's Smithy I can best be compared (Whittle 1991; Kinnes 1992), dates probably to the second half of the thirty-seventh or the first half of the thirty-sixth centuries cal. BC (Morgan 2006), and from this perspective the situation at Wayland's Smithy may appear less unusual. The form of the Wayland's Smithy I barrow is unusual, however, and its size modest, and this can no longer be ascribed to an early date or a putative stage in a developmental sequence, something akin to rotundae, say, which have been seen as developmentally early (Darvill 2004, ch. 3), since our preferred model presented above suggests a date from the mid-thirty-sixth to the mid-thirty-fifth century cal. BC for that barrow.

A second striking feature produced by the dating programme reported above is that the mortuary deposits of Wayland's Smithy I, far from being representative of timeless and general rites in operation through the southern early Neolithic as a whole, acquire an unanticipated and unfamiliar immediacy. There are no signs here of much older remains of possible ancestral status. Though there are a few bone groups, detailed above, with incomplete and disarticulated remains, these are no older than the accumulation of articulated remains, and if not to do with in situ processes of decay or human intervention, may speak rather for some variation in both circumstance and mortuary rite. It is worth repeating the posterior density estimates for the use of Wayland's Smithy I: even at the more cautious probability estimate the site would have been occupied between 1 and 65 years (95\% probability; use Wayland's Smithy I: Fig. 5), and with the less cautious probability estimate, for only 1-15 years (68\% probability). As commented above, the latter estimate is comfortably within a single generation of use.

So what are the circumstances, quite late in the day as it were, which produced such a burst of concentrated accumulation? That it is hard to give a clear answer makes the point we are trying to establish: that the dating programme underlines our lack of wider understanding while refining the chronology of the individual site. It could be tempting to revert to a sense of special or unusual circumstance, to the nineteenth-century idea even of the burial at one time of a 
chieftain or other important person with accompanying attendants and dependants (Thurnam 1869, 185-6, summarized and discussed by Daniel 1950, 106-15). We could modify this to something like a small communal group which suffered illness or injury over a short period of time, or even some kind of war party slain at a particular moment, akin say to the Talheim grave in the LBK (Wahl \& König 1987); the assemblage in the Wayland's Smithy I mortuary deposit includes at least one and potentially three or more individuals who may have suffered possibly lethal arrowhead strikes (and three out of fourteen individuals in one deposit may speak for a significant degree of interpersonal violence), two individuals whose remains were subject to canid scavenging before interment, and it is predominantly both adult and male. This episode belongs to the period after $c .3650 \mathrm{cal}$. вС when causewayed enclosures have been suggested to appear in the upper Thames valley (Barclay 2006), which can be seen as a time of tensions and competition. In such an interpretation, the mortuary deposit of Wayland's Smithy I would find explanation as an episode, an event of special circumstance, within the wider context of the times, rather than as the start of that self-awareness or self-consciousness which may characterize the situation at Ascott-under-Wychwood in the thirty-eighth century cal. вс (Bayliss, Benson et al. this issue).

One argument against such a scenario is that the mortuary structure does not appear a rushed affair; rather, it is carefully built. The mortuary deposits are certainly not jumbled as in the Talheim deposit, and there is a sense of ordered accumulation, carefully placed, in contracted posture, even if now over a much shorter period. If not a circular argument, the likely existence of a lidded wooden box also speaks for successive deposition. So we could fall back on a slightly less specific combination of circumstance and context. What would that be? One answer may rest to a great extent on the sense of context and change through time. There is no great body of evidence for occupation of the high downland where Wayland's Smithy lies in the Neolithic as a whole (summarized in Whittle 1991). Wayland's Smithy I incorporates artefacts and evidence of limited previous occupation and activity possibly involving some clearance and cultivation (Whittle 1991, 92). One of the few neighbouring long barrows, at Lambourn, has now been better dated, to the thirty-eighth or thirty-seventh century cal. ВС (Schulting 2000). The three reliable dates from Lambourn come from the ditch, and only two of them from the base of the ditch. These two (OxA-7692, 4870 \pm 45 вр, and OxA-7694, 4915 \pm 45 вг) are statistically consistent $\left(T^{\prime}=0.5 ; T^{\prime}(5 \%)=3.8\right.$; $v=1$ ) and suggest that Lambourn may be slightly earlier than Wayland's Smithy I, perhaps falling in the earlier part of the thirty-seventh century cal. BC. So while there are inevitably uncertainties surrounding its chronology, the Lambourn long barrow could date to slightly earlier than the start of Wayland's Smithy. At a similar date in the upper Thames valley, from the thirty-seventh into the thirty-sixth centuries cal. $\mathrm{BC}$, by contrast, there had already been centuries of more visible occupation, and causewayed enclosures had appeared in some numbers from perhaps the middle of the thirty-seventh century cal. вс (Barclay 2006). From this perspective, we could see what was going on at locations like Wayland's Smithy and Lambourn as the intake of previously peripheral situations, with small groups laying claim to summer pasture or land otherwise valuable to them. That scenario relies heavily on a sense of context, and says far less about the specific circumstances that led to a burst of quite rapid deposition and the emphasis on adult males. There is too, an air of sudden abandonment, or unexpected curtailment of mortuary use, perhaps more so here than at West Kennet at the end of the primary deposition phase there (Bayliss, Whittle \& Wysocki this issue). The empty, southern half of the mortuary paving suggests a structure ultimately unfulfilled, a space reserved but never, seemingly, utilized, reflecting perhaps the ad hoc nature of such episodic use. But the likely existence of a gap between the use of the mortuary structure and the mound of Wayland's Smithy I does indicate a place where associations were maintained over a longer period of time.

Attachment to place could be one way to think about the later history of Wayland's Smithy, if a rather general one. A further gap ensued between Wayland's Smithy I and the initiation of Wayland's Smithy II; in our preferred model above this gap was of some 1-75 years (95\% probability; I \& II: Fig. 5), probably of 1-35 years $(68 \%$ probability). Over this kind of timespan the site was not forgotten. In our preferred model, Wayland's Smithy II was initiated as a unitary construction, though we have raised the possibility of a different kind of building history, and this took place in the thirty-fifth to thirty-fourth centuries cal. BC (3490-3390 cal. BC (95\% probability; start Wayland's Smithy II: Fig. 4); in our preferred model, the use of this monument ended probably in the middle decades of the thirty-fourth century cal. вс. The evidence here is more constrained, but this appears now a strikingly late phenomenon. It is certainly later than the comparable monument of West Kennet (Bayliss, Whittle \& Wysocki this issue), though it is probably too soon to say whether it 
is later than all other transepted monuments, given seemingly quite late dates from Millbarrow (Whittle 1994). The end of use of Wayland's Smithy II might not long precede, and could even overlap, the appearance of cursus monuments in the upper Thames valley and elsewhere (Barclay \& Bayliss 1999).

By comparison with West Kennet, the form monumentalized at Wayland's Smithy II would already have been old. We are denied better understanding of the rites of deposition in this phase of the monument by the poor survival of the deposits. We could refer the style of monument simply to some generalized notion of tradition, but the form chosen might suggest a more conscious harking back to ideas and practices already old. If there was still a need to lay claim to place and land, part of the possession of this location may have been seen now to reside in a sense of history. There has been some discussion in the literature about the creation of deliberately archaic forms in Cotswold monuments, focusing on the treatment of the flanks of cairns (Grimes 1960; Darvill 1982; Britnell 1984; Saville 1990). While the specific issue of 'extra-revetment' material now looks less likely to be the basis for such a practice, form as a whole could be a much more potent tool in the deliberate creation of history and myth. With these results, we can no longer assume that a particular form of architecture goes with a particular form of deposition and identical context (compare Thomas 1988). Creating Wayland's Smithy II in this particular form would align both its builders and the forebears already interred in Wayland's Smithy I with the heroic earlier generations who set up West Kennet and Windmill Hill, some 25-30 $\mathrm{km}$ to the southwest, whose renown could still have echoed some 150 years or so later around the downland communities and beyond.

\section{Notes}

1. We have retained the numbering system used in Whittle (1991). Dating samples are given as ws1, ws2, etc.

2. It should be noted that the laboratory number for this sample was incorrectly given as I-2328 in Whittle (1991, 80), following Council for British Archaeology (1971).

3. The non-soluble fraction remaining after the separation of the bone gelatin was also dated, producing a result of $4485 \pm 35$ вр (with а $\delta^{13} \mathrm{C}$ value of $-21.8 \%$ o $)$. The age difference of $295 \pm 53$ вр $(\sim 5.6 \sigma)$ indicates contaminants of more recent age in the sample. As filtering removes nonsoluble contaminants from the gelatin and concentrates them in the residue, and the gelatin fraction contained nine times more carbon than the residue fraction, the age of the gelatin should be reliable. The organic filter residues of the three other samples yielded well below $1 \mathrm{mg}$ of carbon, not enough for a precise and reliable AMS measurement.

\section{Acknowledgements}

The radiocarbon dating programme reported here was funded by English Heritage. We thank Chris Welch for every assistance. We are grateful to the staff of the Oxford Radiocarbon Accelerator Unit and the Leibniz Labor für Altersbestimmung und Isotopenforschung, ChristianAlbrechts-Universität, Kiel, for dating these samples. The re-analysis of the human bone assemblage was undertaken as part of a project funded by the Leverhulme Trust. Finally, we are grateful to Jill Greenaway for help in tracking down the Wayland's Smithy I arrowheads and, together with the Trustees of Reading Museum, for permission to examine and sample material from their collection. Andrew David, Ollie Harris, Frances Healy, Jonathan Last, Peter Marshall and Rick Schulting commented usefully on earlier drafts of this paper.

\section{References}

Ashbee, P., 1966. The Fussell's Lodge long barrow excavations 1957. Archaeologia 100, 1-80.

Ashbee, P., 1970. The Earthen Long Barrow in Britain. London: Dent.

Ashmore, P.J., 1999. Radiocarbon dating: avoiding errors by avoiding mixed samples. Antiquity 73, 124-30.

Atkinson, R.J.C., 1965. Wayland's Smithy. Antiquity 39, $126-33$.

Barclay, A., 2006. Connections and networks: a wider world and other places, in Building Memories: the Neolithic Cotswold Long Barrow at Ascott-under-Wychwood, Oxfordshire, eds. D. Benson \& A. Whittle. Oxford: Oxbow, 331-44.

Barclay, A.J. \& A. Bayliss, 1999. Cursus monuments and the radiocarbon problem, in Pathways and Ceremonies: the Cursus Monuments of Britain and Ireland, eds. A. Barclay \& J. Harding. Oxford: Oxbow, 11-29.

Bayliss, A. \& C. Bronk Ramsey, 2004. Pragmatic Bayesians: a decade integrating radiocarbon dates into chronological models, in Tools for Constructing Chronologies: Tools for Crossing Disciplinary Boundaries, eds. C.E. Buck \& A.R. Millard. London: Springer, 25-41.

Bayliss, A., C. Bronk Ramsey \& F.G. McCormac, 1997. Dating Stonehenge, in Science and Stonehenge, eds. B. Cunliffe \& C. Renfrew. Oxford: British Academy, 39-59.

Bayliss, A., C. Bronk Ramsey, J. van der Plicht \& A. Whittle, this issue. Bradshaw and Bayes: towards a timetable for the Neolithic.

Bayliss, A., D. Benson, D. Galer, L. Humphrey, L. McFadyen \& A. Whittle, this issue. One thing after another: the date of the Ascott-under-Wychwood long barrow.

Bayliss, A., A. Whittle \& M. Wysocki, this issue. Talking about my generation: the date of the West Kennet long barrow.

Britnell, W.J., 1984. The Gwernvale long cairn, Crickhowell, Brecknock, in Gwernvale and Penywyrlod: Two Neolithic Long Cairns in the Black Mountains of Brecknock, eds. W.J. Britnell \& H.N. Savory. Cardiff: Cambrian Archaeological Association, 42-154. 
Bronk Ramsey, C., 1995. Radiocarbon calibration and analysis of stratigraphy. Radiocarbon 36, 425-30.

Bronk Ramsey, C., 1998. Probability and dating. Radiocarbon 40, 461-74.

Bronk Ramsey, C., 2001. Development of the radiocarbon calibration program. Radiocarbon 43, 355-63.

Bronk Ramsey, C., P.B. Pettitt, R.E.M. Hedges, G.W.L. Hodgins \& D.C. Owen, 2000. Radiocarbon dates from the Oxford AMS system: Archaeometry datelist 30. Archaeometry 42, 459-79.

Bronk Ramsey, C., T.F.G. Higham, A. Bowles \& R.E.M. Hedges, 2004a. Improvements to the pre-treatment of bone at Oxford. Radiocarbon 46, 155-63.

Bronk Ramsey, C., T. Higham \& P. Leach, 2004b. Towards high precision AMS: progress and limitations. Radiocarbon 46, 17-24.

Brothwell, D.R. \& R. Cullen, 1991. The human bone, in A. Whittle, 'Wayland's Smithy, Oxfordshire: excavations at the Neolithic tomb in 1962-63 by R.J.C. Atkinson and S. Piggott'. Proceedings of the Prehistoric Society 57(2), 61-101.

Council for British Archaeology, 1971. Archaeological Site Index to Radiocarbon Dates for Great Britain and Ireland. London: Council for British Archaeology.

Corcoran, J.X.W.P., 1969a. The Cotswold-Severn group. 1. Distribution, morphology and artefacts, in Megalithic Enquiries in the West of Britain, eds. T.G.E. Powell, J.X.W.P. Corcoran, F. Lynch \& J.G. Scott. Liverpool: Liverpool University Press, 13-72.

Corcoran, J.X.W.P., 1969b. The Cotswold-Severn group. 2. Discussion, in Megalithic Enquiries in the West of Britain, eds. T.G.E. Powell, J.X.W.P. Corcoran, F. Lynch \& J.G. Scott. Liverpool: Liverpool University Press, 73-104.

Daniel, G.E., 1950. The Prehistoric Chamber Tombs of England and Wales. Cambridge: Cambridge University Press.

Darvill, T., 1982. The Megalithic Chambered Tombs of the Cotswold-Severn Region. Highworth: Vorda.

Darvill, T., 2004. Long Barrows of the Cotswolds and Surrounding Areas. Stroud: Tempus.

Green, H.S., 1980. The Flint Arrowheads of the British Isles. (British Archaeological Reports, British Series 75.) Oxford: BAR.

Grimes, W.F., 1960. Excavation on Defence Sites 1939-45, vol. I: Mainly Neolithic and Bronze Age. London: Her Majesty's Stationery Office.

Grootes, P.M., M.-J. Nadeau \& A. Rieck, 2004. ${ }^{14}$ C-AMS at the Leibniz-Labor: radiometric dating and isotope research. Nuclear Instruments and Methods in Physics Research B 223-224, 55-61.

Haglund, W.D., 1997. Dogs and coyotes: postmortem involvement with human remains, in Forensic Taphonomy: the Postmortem Fate of Human Remains, eds. W.D. Haglund \& M.H. Sorg. Boca Raton (FL): CRC Press, 367-81.

Hedges, R.E.M., C.R. Bronk \& R.A. Housley, 1989. The Oxford accelerator mass spectrometry facility; technical developments in routine dating. Archaeometry 31, 99-113.

Hodder, I. \& P. Shand, 1988. The Haddenham long barrow: an interim statement. Antiquity 62, 349-53.

Law, I.A. \& R.E.M. Hedges, 1989. A semi-automated pretreatment system and the pretreatment of older and contaminated samples. Radiocarbon 31, 247-53.

Kinnes, I., 1975. Monumental function in British Neolithic burial practices. World Archaeology 7, 16-29.

Kinnes, I., 1992. Non-megalithic Long Barrows and Allied Structures in the British Neolithic. London: British Museum.

Manhein, M.H., 1997. Decomposition rates of deliberate burials: a case study of preservation, in Forensic Taphonomy: the Postmortem Fate of Human Remains, eds. W.D. Haglund \& M.H. Sorg. Boca Raton (FL): CRC Press, 469-81.

Mant, A.K., 1987. Knowledge acquired from post-War exhumations, in Death, Decay and Reconstruction, eds. A. Boddington, A.N. Garland \& R.C. Janaway. Manchester: Manchester University Press, 65-80.

Mays, S., 1998. The Archaeology of Human Bones. London: Routledge.

Meadows, J., A. Barclay \& A. Bayliss, this issue. A short passage of time: the dating of the Hazleton North long cairn revisited.

Morgan, R., 2006. Tree ring results, in A Woodland Archaeology: Neolithic Sites at Haddenham, eds. C. Evans \& I. Hodder. (McDonald Institute Monographs.) Cambridge: McDonald Institute for Archaeological Research, 177-87.

Nadeau, M.-J., M. Schleicher, P. M. Grootes, H. Erlenkeuser, A. Gottdang, D.J.W. Mous, J.M. Sarnthein \& H. Willkomm, 1997. The Leibniz-Labor AMS facility at the Christian-Albrechts University, Kiel, Germany. Nuclear Instruments and Physics Research B 123, 22-30.

Nadeau, M.-J., P.M. Grootes, M. Schleicher, P. Hasselberg, A. Rieck \& M. Bitterling, 1998. Sample throughput and data quality at the Leibniz-Labor AMS facility. Radiocarbon 40, 239-45.

Peers, C.R. \& R.A. Smith, 1921. Wayland's Smithy, Berkshire. Antiquaries Journal 1, 183-98.

Piggott, S., 1958. The excavation of the West Kennet long barrow: 1955-6. Antiquity 32, 235-42.

Reimer, P.J., M.G.L. Baillie, E. Bard, A. Bayliss, J.W. Beck, C.J.H. Bertrand, P.G. Blackwell, C.E. Buck, G.S. Burr, K.B. Cutler, P.E. Damon, R.L. Edwards, R.G. Fairbanks, M. Friedrich, T.P. Guilderson, A.G. Hogg, K.A. Hughen, B. Kromer, F.G. McCormac, S. Manning, C. Bronk Ramsey, R.W. Reimer, S. Remmele, J.R. Southon, M. Stuiver, S. Talamo, F.W. Taylor, J. van der Plicht \& C.E. Weyhenmeyer, 2004. IntCal04 Terrestrial Radiocarbon Age Calibration, 0-26 cal kyr вр. Radiocarbon 46, 1029-58.

Rodriguez, W.C., 1997. Decomposition of buried and submerged bodies, in Forensic Taphonomy: the Postmortem Fate of Human Remains, eds. W.D. Haglund \& M.H. Sorg. Boca Raton (FL): CRC Press, 459-67.

Roksandić, M., 2002. Position of skeletal remains as a key to understanding mortuary behaviour, in Advances in Forensic Taphonomy: Method, Theory and Archaeological Perspectives, eds. W.D. Haglund \& M.H. Sorg. Boca 
Raton (FL): CRC Press, 99-117.

Saville, A., 1979. Further excavations at Nympsfield chambered tomb, Gloucestershire, 1974. Proceedings of the Prehistoric Society 45, 53-92.

Saville, A., 1990. Hazleton North: the Excavation of a Neolithic Long Cairn of the Cotswold-Severn Group. London: English Heritage.

Schulting, R.J., 2000. New AMS dates from the Lambourn long barrow and the question of the earliest Neolithic in southern England: repacking the Neolithic package? Oxford Journal of Archaeology 19, 25-35.

Schulting, R.J. \& M. Wysocki, 2005. 'In this chambered tumulus were found cleft skulls...': an assessment of the evidence for cranial trauma in the British Neolithic. Proceedings of the Prehistoric Society 71, 107-38.

Stuiver, M. \& H.A. Polach, 1977. Reporting of ${ }^{14} \mathrm{C}$ data. Radiocarbon 19, 355-63.

Stuiver, M. \& P.J. Reimer, 1986. A computer program for radiocarbon age calculation. Radiocarbon 28, 1022-30.

Stuiver, M. \& P.J. Reimer, 1993. Extended ${ }^{14} \mathrm{C}$ data base and revised CALIB $3.0{ }^{14} \mathrm{C}$ age calibration program. Radiocarbon 35, 215-30.

Thomas, J., 1988. The social significance of Cotswold-Severn burial rites. Man 23, 540-59.

Thomas, J., 1991. Rethinking the Neolithic. Cambridge: Cambridge University Press.

Thurnam, J., 1869. On ancient British barrows, especially those of Wiltshire and the adjoining counties (part I, long barrows). Archaeologia 42, 161-244.

Wahl, J. \& H.G. König, 1987. Anthropologisch-traumatologische Untersuchung der menschlichen Skelettreste aus dem bandkeramischen Massengrab bei Talheim, Kr. Heilbronn. Fundberichte aus Baden-Württemberg 12, 65-186.

Walton, A., M.A. Trautman \& J.P. Friend, 1961. Isotopes Inc. Radiocarbon Measurements I. Radiocarbon 3, 47-59.

Ward, G.K. \& S.R. Wilson, 1978. Procedures for comparing and combining radiocarbon age determinations: a critique. Archaeometry 20, 19-31.

Whittle, A., 1991. Wayland's Smithy, Oxfordshire: excavations at the Neolithic tomb in 1962-63 by R.J.C. Atkinson and S. Piggott. Proceedings of the Prehistoric Society 57 (2), 61-101.

Whittle, A., 1994. Excavations at Millbarrow chambered tomb, Winterbourne Monkton, north Wiltshire. Wiltshire Archaeological and Natural History Magazine $87,1-53$.

Whittle, A. \& M. Wysocki, 1998. Parc le Breos Cwm transepted long cairn, Gower, West Glamorgan: date, contents and context. Proceedings of the Prehistoric Society 64, 139-82.

Wysocki, M. \& A. Whittle, in preparation. On the people of the long barrows: human skeletal remains from West Kennet, Wayland's Smithy and Fussell's Lodge.

Wysocki, M., A. Bayliss \& A. Whittle, this issue. Serious mortality: the date of the Fussell's Lodge long barrow. 
